\title{
DEVELOPMENT OF LAND RELATIONS IN THE CONTEXT OF GOVERNMENT DECENTRALIZATION IN UKRAINE
}

\author{
N. Palapa ${ }^{1}$, N. Pron ${ }^{1}$, O. Ustymenko ${ }^{2}$ \\ ${ }^{1}$ Інститут агроекології і природокористування НААН \\ 2 Дослідна станція лікарських рослин ІАП НААН
}

\begin{abstract}
Визначено суть та доцільність проведення децентралізаційної реформи в Україні, зокрема щодо ї̈ впливу на подальший розвиток сільських територій. Увагу зосереджсено на питаннях земельних відносин як ефективного інструменту управління новостворених об'єднаних територіальних громад. Проаналізовано нинішній стан функціонування та діяльності особистих селянських господарств як представників малого агробізнесу на сільських територіях в Україні. Розглянуто питання доцільності утворення локальних агропродовольчих ринків з метою реалізації сільськогосподарської продукції. Висвітлено можливі загрози у процесі об'єднання територіальних громад унаслідок недостатнього дослідження питань екологічного стану на цих територіях, а також їх соціальноекономічного розвитку. Розглянуто європейський досвід проведення реформ місиевого самоврядування, зокрема особливостей функціонування найменших адміністративних одиниць у Республіці Польща - гмін. Підсумовано результати проведення адміністративно-територіальної реформи в Україні та висвітлено інформацію щодо утворення та функціонування об'єднаних територіальних громад у регіональному розрізі.
\end{abstract}

Ключові слова: децентралізаційна реформа, сільські території, земельні відносини, об'єднана територіальна громада, особисті селянські господарства, сільськогосподарська продукція.

The issues of sustainable rural development in Ukraine are especially actual today, when processes of power decentralization, local government reforms and European integration are being actively provided. In view of this, rural area is the subject of many scientific researches in the field of governmental regulation, regional development and social policy. The famous Ukrainian scientist O. Pavlov notes that «... the condition in which peasantry is being today is contradictable to its state-building status. Social changes that took place in the Ukrainian state in the past two decades, did not contribute to the removal of the peasantry to the required level of statebuilding, caused a threatening situation not only for it but also for the further existence of Ukraine as a sovereign state» [1].

No less important rural area is also for the agricultural sector development, food industry, environmental economics, agro-ecology

(C) N. Palapa, N. Pron, O. Ustymenko, 2016 and environmental management. Researches of the condition and development tendencies of rural areas is a priority task also for the simple reason that questions concerning possession and using of land plots that are located outside rural areas remains unsolved till these days, because agricultural land is the main instrument for gaining income in rural areas. All of this constitutes the relevance of the selected research theme.

\section{RESEARCH MATERIALS}

It should be mentioned that reforming administrative and territorial structure in Ukraine was a matter of time and a necessary condition for village overcoming from systemic crisis, that is accompanied by rapid demographic decline and numerous migration flows, decrease of social and engineering infrastructure, reducing the share of rural employment and workplaces in rural territories. As a result of such situation the ecological state continued to escalate over there. 
To such a situation have also contributed the reasons of state indifference and legislative disorder towards functioning of small agricultural business - so called personal peasant households. Comparing with the activities of farmers and powerful agricultural enterprises (agro-holdings), owners of personal peasant households are not able to compete in the process of rational land using. That is why they do not have opportunity to be fully engaged into the agricultural chain because of the following important reasons [2]: lack of government subsidies, grants and accessible crediting, very small amount of a land plot, dominance of manual labor over mechanical and automated one, absence of technical support (tractors, combines, etc.), impossibility of complete realization of agricultural production (as a rule this production is realized on spontaneous markets without prior conducting of expert evaluation of agricultural production quality that is characterized by a lack of agrochemical examination of soil, surface water and underground water, etc.).

The problem of a large number of spontaneous markets in Ukraine has been tried to be solved by creating special agricultural local markets. However, experience has shown that today opportunities for the development of agroindustrial market in our local communities is not very successful. Nationwide decline in production that is the lowest during all the periods of Ukrainian independence and decrease of personal purchasing power, rapid growth of energy costs - all this have a negative affect on the market development in general, and agroindustrial in particular. Another very important reason is the absence of our consumer understanding that there is «massive» agricultural production from agricultural holdings with the full range of chemicals that are used in its cultivation and there is another - agricultural production from personal peasant households or small farmers, more or less eco-friendly, and therefore it should be much more expensive. Spontaneous or civilized markets near the roadways in Ukraine are also unpromising today, as the number of buyers travelling along the roads is rather small. Rather interesting variant is creation of virtual shopping site (internetmarket) of agricultural production with the services and opportunity to make reservations via the Internet and delivery the necessary products not only locally, but also to the nearest large settlements. Unfortunately this direction has not been developed in Ukraine.

However, more realistic is the idea of agricultural fairs organization, for example, at least once a week in a district center. Those owners of personal peasant households who wish to sell their production could rent the necessary transport to provide a comfortable and safe route of agricultural products exportation to the district center. In addition, high demand could have the products of organic agriculture, but it requires to have a starting capital for the appropriate organization of such kind of business. As a consequence another way was chosen - creation of agricultural cooperatives, which are the connection link between agricultural producers and consumers.

Nowadays it is also important to consider the consequences of climate changes, increasing greenhouse effect and drought or conversely - sudden increase in rains, downpours and hail. The main fact is that agricultural activity in Ukraine is a seasonal business and directly dependent on natural and climatic features. In Ukraine natural and technogenic catastrophes have been recently observed even more often and anthropogenic impact on the the natural landscape increases dramatically, as a result the level of ecological danger is constantly growing [3]. Along with agriculture, the role of ecological safety increases also in the forestry and fish industry, and therefore requires carrying out comprehensive scientific researches in order to improve the level of ecological safety, as these industries are harmoniously connected and interdependent of each other.

The ecological and agro-ecological condition on rural areas is worsening annually because of deterioration of socio-economic situation, as well as improper depletion of agricultural lands by powerful agricultural enterprises on rural areas. That is why it causes the declining of the world's best lands - 
Table 1

Gmina Expenditures in Principal Sectors, years [5]

\begin{tabular}{l|r|r|r|r}
\hline \multicolumn{1}{c|}{ Function } & 1991 & 1994 & 1996 & 1999 \\
\hline \hline Agriculture & 3.1 & 2.3 & 2.3 & 2.0 \\
Transportation & 2.9 & 1.9 & 1.8 & 2.2 \\
Public utilities & 28.0 & 26.8 & 22.3 & 22.2 \\
Housing & 7.8 & 6.7 & 4.2 & 4.7 \\
Education & 16.0 & 25.5 & 37.4 & 36.7 \\
Culture and arts & 3.9 & 3.3 & 2.7 & 2.8 \\
Health care & 7.0 & 8.7 & 6.1 & 6.1 \\
Public welfare & 7.7 & 9.9 & 9.2 & 9.6 \\
Administration & 10.4 & 10.3 & 9.7 & 9.7 \\
Subsidies & 8.4 & 0.7 & 0.2 & 0.1 \\
Other & 4.8 & 3.9 & 4.1 & 3.9 \\
\hline
\end{tabular}

Ukrainian black soils, useful properties and soil fertility are being deteriorated and the content of heavy metals in the soil increases rapidly, as well as erosion and deflation process of soil, agricultural production is often contaminated with various chemical microelements in extremely impermissible concentrations. And if the owners of farms or agricultural holdings can afford conducting laboratory examination of agricultural production quality, the owners of personal peasant households have no such opportunity due to the large financial expenditures of such surveys.

Thus, decentralization reform in Ukraine, which involves the power transfer to the lowest level of government - local communities, is essential process through which village will be revived and improve its development. The evidence of this is conducted before decentralization reforms in many European countries [4], in particular in Poland (Table 1), etc.

\section{RESULTS AND DISCUSSION}

It is expedient to consider the prerequisites of decentralized reform in Ukraine. So the administrative-territorial structure of Ukraine was inherited from the former Soviet Union and is characterized by a high level of power centralization. In addition, the representative bodies at the local level have not become leaders of effective policy of human interests and ensuring protection of the urgent needs of communities. Low efficiency of local government activities in a large extent is caused by inadequate level of budget financing mechanism and the lack of transfer of financial resources to the level of local communities [6].

The excessive centralization of power, its inefficient organization at the regional level, non-ability of local government still remain a problem in Ukrainian society. Decentralization of power includes both political and administrative components. It can be territorial - the removement of power authority from the central city to other territories, and may be functional - by granting authority on decision making from the main authority of any branch of government to government officials of lower levels [7]. This process was called «new government management», which was described as decentralization, objective management, competition of local and government coordination [8].

According to the European Charter of Local Self-Government of 15 October 1985 [9], the content of local government consists of guaranteed by the state law and the real ability of local communities of most citizens (local groups) and formed by them authorities independently and under its responsibility solve a specific part of public affairs, acting within the constitution norms and laws of appropriate state. Local government bodies acknowledged as one of the main foundations of any democratic society. 
On June 17, 2014 the Supreme Council of Ukraine adopted the first package of «decentralization laws» - the Law of Ukraine «On cooperation of territorial communities». Thus decentralisation implies the creation of financially independent communities that can separately at an adequate level maintain kindergartens and schools, outpatient clinics, cultural centers and clubs, roads, infrastructure etc. of a particular settlement. In short, decentralization is a real way to improve the quality of daily life of the inhabitants of each village, town or city. European and international experience shows that problems of a particular settlement can be effectively resolved only locally. Decentralization involves the transfer of authority to solve local problems on the community level, ensuring them by their own financial resources that will make them able to resolve these problems. Thus, power decentralization reform requires resolving the following five key tasks:

1) to determine the territorial basis of local government and executive power;

2) to delimit authority between local governments at various levels;

3) to delimit authority between local governments and the executive power;

4) to determine the necessary amount of resources at each level;

5) to provide accountability of local government to electorate and state.

However, the key to the actual implementation of such reforms should be excellent level of communication, interaction with all relevant stakeholders and the public. Considering this in Ukraine appeared a new concept - self-sufficient communities. Under the self-sufficiency of territorial communities we understand the ability by their own activities to create and play back necessary social and economic conditions to satisfy needs of their population by activating the internal resources of rural areas. The main signs of self-sufficient communities are: pital;

- expanded reproduction of human ca-

- availability of own developed economic system and its high adaptive capacities in the external environment;
- available for rural population social mechanism of meeting the needs;

- organizational and financial autonomy and legal capacity of local governments;

- well-balanced, ecological and economic justification of resource potencial usage of the community to create favorable living environment for its residents;

- participation and adequate control of community residents of both internal and external relationships and processes regarding their life at all levels, from the highest (state) to the lowest (local);

- integration of residents into socio-economic processes of their community and their effective cooperation, solidarity and partnership.

As a multi-functional systems rural communities should have an appropriate set of subsystems and components that must function in appropriate manner. Based on the fact that rural area as a system has the following components as economic, social, environmental, management, our research shows that self-sufficient community should have a set of institutions necessary for its full functioning. Their minimal set is: production industry, industrial infrastructure and social infrastructure, housing and utilities infrastructure, governing bodies.

It should be noted that since 1991 in Ukraine the number of rural population has decreased by 2.5 million persons and the number of villages - to 348 units. At the same time number of Village Councils increased by 1.067 units. In 2015 in Ukraine about 12 thousand of territorial communities were formed and in more than 6 thousand territorial communities the number of residents is less than 3 thousand people (in 4809 territorial communities is less than one thousand people and in 1129 - less than 500), in the majority of them executive bodies of Village Councils were not formed, there are no budget organizations, utilities etc. Local government bodies of such communities practically cannot implement given for them by law authorities.

The table 2 shows that in 2015, 794 village, town and city councils, which include 
Table 2

Basic information about United Territorial Communities (UTC) in Ukraine in the process of decentralization, 2015 [10]

\begin{tabular}{|c|c|c|c|c|c|c|}
\hline \multirow{2}{*}{ Regions of Ukraine } & \multirow{2}{*}{$\begin{array}{l}\text { Number } \\
\text { of UTC }\end{array}$} & \multirow{2}{*}{$\begin{array}{c}\text { Number } \\
\text { of human } \\
\text { settlements }\end{array}$} & \multicolumn{2}{|c|}{ Square, $\mathrm{km}^{2}$} & \multirow{2}{*}{$\begin{array}{c}\text { Square } \\
\text { percentage of } \\
\text { UTC in total } \\
\text { area of region, \% }\end{array}$} & \multirow{2}{*}{$\begin{array}{c}\text { Population } \\
\text { percentage of } \\
\text { UTC in total } \\
\text { area of region, \% }\end{array}$} \\
\hline & & & $\begin{array}{c}\text { Regions } \\
\text { of Ukraine }\end{array}$ & UTC & & \\
\hline Ternopil & 26 & 283 & 13823 & 3830 & 27.7 & 21.3 \\
\hline Khmelnytsky & 22 & 490 & 20645 & 7414 & 35.9 & 23 \\
\hline Dnipropetrovsk & 15 & 159 & 31914 & 3982 & 12.5 & 4.1 \\
\hline Lviv & 15 & 151 & 21833 & 1107 & 5.1 & 2.6 \\
\hline Poltava & 12 & 179 & 28748 & 2101 & 7.3 & 6 \\
\hline Chernivsti & 10 & 45 & 8097 & 768 & 9.5 & 9 \\
\hline Zhytomyr & 9 & 152 & 29832 & 2573 & 8.6 & 4.1 \\
\hline Odessa & 8 & 98 & 33310 & 2586 & 7.8 & 3.6 \\
\hline Zaporizhia & 6 & 57 & 27180 & 2262 & 8.3 & 2.2 \\
\hline Volyn & 5 & 80 & 20144 & 1094 & 5.4 & 2.6 \\
\hline Rivne & 5 & 41 & 20047 & 948 & 4.7 & 2.3 \\
\hline Chernihiv & 5 & 57 & 31865 & 1678 & 5.3 & 2.3 \\
\hline Donetsk & 3 & 65 & 26517 & 1738 & 6.6 & 1.3 \\
\hline Ivano-Frankivsk & 3 & 26 & 13900 & 409 & 2.9 & 2.5 \\
\hline Cherkasy & 3 & 12 & 20900 & 381 & 1.8 & 1.5 \\
\hline Vinnytsia & 2 & 14 & 26513 & 218 & 0.8 & 1.5 \\
\hline Zakarpattia & 2 & 6 & 12777 & 168 & 1.3 & 2.5 \\
\hline Kirovohrad & 2 & 25 & 24588 & 426 & 1.7 & 2.6 \\
\hline Luhansk & 2 & 30 & 26684 & 1014 & 3.8 & 1.2 \\
\hline Kiev & 1 & 6 & 28131 & 211 & 0.7 & 0.6 \\
\hline Mykolaiv & 1 & 4 & 24598 & 229 & 0.9 & 0.3 \\
\hline Sumy & 1 & 21 & 23834 & 465 & 2 & 0.5 \\
\hline Kherson & 1 & 14 & 28461 & 206 & 0.7 & 0.3 \\
\hline Kharkiv & 0 & 0 & 31415 & 0 & 0 & 0 \\
\hline Totally & 159 & 794 & 2015 & 575756 & 6.2 & 3.5 \\
\hline
\end{tabular}

2015 settlements, voluntarily united into 159 territorial communities (hereinafter UTC). The largest number of UTC was established in Ternopil (26) and Khmelnytsky region (22). The total area of UTC was $35807 \mathrm{~km}^{2}$, that represents $5.9 \%$ of the total area of Ukraine (excluding Kyiv and Crimea Autonomous Republic) [10].

\section{CONCLUSIONS}

The most important role in the decentralization process plays local government reform and territorial organization of power according to the main provisions of European integration concept. Under these conditions, rural area gets a special status in Ukraine, which from this time is a structural unit of united territorial community. This is where the key issue of land relation reforming on rural areas. Also in the context of decentralization first step for the sustainable development of rural areas and territorial communities is the formation of a common vision and action plan towards the implementation of main decentralization goals - to create a strategy of territorial community development, taking into account not only social and economic but also ecological features. Our further scientific researches would be devoted to the highlighting of this issue. 


\section{ЛІТЕРАТУРА}

1. Павлов O.I. Українське селянство як дзеркало процесу державотворення [Електронний ресурс] / О.І. Павлов // Актуальні проблеми державного управління. - 2011. - № 1. - С. 302-308. - Peжим доступу: http://nbuv.gov.ua/UJRN/apdy_ 2011137

2. Гиатів Н.Б. Соціально-економічні та агроекологічні проблеми сільських територій / Н.Б. Гнатів // Збалансоване природокористування. - 2014. № 4. - C. 84-86.

3. Нагірна В.П. Можливі загрози сільському господарству України з позицій екобезпеки [Електронний ресурс] / В.П. Нагірна, І.Г. Савчук // Економіка України. - 2014. - № 2. - С. 71-83. Режим доступу: http://nbuv.gov.ua/UJRN/EkUk 2014_2_7

4. European Commission. EU Land Policy Guidelines [Електронний ресурс]. - Режим доступу: https:// ec.europa.eu/europeaid/sites/devco/files/methodology-eu-land-policy-guidelines-200411_en_2.pdf

5. Regulski J. Local government reform in Poland. An insider's story [Електронний ресурс] / J. Regulski. London: Open Society Institute, 2003. - Режим доступу: http://unpan1.un.org/intradoc/groups/ public/documents/untc/unpan012822.pdf
6. Верещук I.A. Особливості територіальної організації влади Львівської області / I.А. Верещук // Економічний часопис - XXI. - 2011. - № 9-10. C. 54-56.

7. Definition of decentralization, Merriam-Webster Dictionary [Електронний ресурс]. - Режим доступу: http://www.merriam-webster.com/dictionary/decentralization

8. Managing Decentralisation: A New Role for Labour Market Policy, Organisation for Economic Cooperation and Development, Local Economic and Employment Development (Program), OECD Publishing, 2003. - 135 p.

9. Європейська хартія місцевого самоврядування (Страсбург, 15.10.1985 р.); Хартію ратифіковано Законом № 452/97-ВР від 15.07.97 (Дата підписання: 6.11.1996 р.) [Електронний ресурс]. - Peжим доступу: http://zakon.rada.gov.ua

10. Фінансова децентралізація в дії [Електронний ресурс] / Офіційний сайт Міністерства регіонального розвитку, будівництва та житловокомунального господарства України. - Режим доступу: http://www.minregion.gov.ua/decentralization/presentation/finansova-detsentralizatsiyav-diyi

\section{REFERENCES}

1. Pavlov O.I. (2011). Ukrayinske selyanstvo yak dzerkalo procesu derzhavotvorennya [Ukrainian peasantry as a mirror of the process of state building]. Aktualni problemy derzhavnogo upravlinnya [Actual problems of state administration], No. 1, pp. 302-308. Available at: http://nbuv.gov.ua/UJRN/apdy_2011_1_37 (in Ukrainian).

2. Gnativ N.B. (2014). Socialno-ekonomichni ta agroekologichni problemy silskyx terytorij [Socio-economic and agroecological problems of rural areas]. Zbalansovane pryrodokorystuvannia [Balanced Nature Management], No. 4, pp. 84-86 (in Ukrainian).

3. Nahirna V. P., Savchuk I. H. (2014). Mozhlyvi zahrozy silskomu hospodarstou Ukrainy z pozytsii ekobezpeky [Possible threats to agriculture of Ukraine from the standpoint of ecological safety]. Ekonomika Ukrainy [Economy of Ukraine], No. 2, pp. 71-83. Available at: http://nbuv.gov.ua/UJRN/EkUk_2014_2_7 (in Ukrainian).

4. European Commission. EU Land Policy Guidelines. Available at: https://ec.europa.eu/europeaid/sites/ devco/files/methodology-eu-land-policy-guidelines200411_en_2.pdf (in English).

5. Regulski J. (2003). Local government reform in Poland. An insider's story. London: Open Society Institute. Available at: http://unpan1.un.org/intra- doc/groups/public/documents/untc/unpan012822. pdf (in English).

6. Vereshchuk I.A. (2011). Osoblyvosti terytorialnoi orhanizatsii vlady Lvivskoi oblasti [Features of territorial organizayion of authorities of Lviv region] Ekonomichnyi chasopys - XXI [Economic Journal XXI], No. 9-10, pp.54- 56 (in Ukrainian).

7. Definition of decentralization, Merriam-Webster Dictionary Available at: Access: http://www.merriam-webster.com/dictionary/decentralization (in English).

8. Managing Decentralisation: A New Role for Labour Market Policy, Organisation for Economic Cooperation and Development, Local Economic and Employment Development (Program), OECD Publishing, 2003, p. 135 (in English).

9. The European Charter of Local Self-Government, Strasbourg, 15 October 1985. Available at: http:// www.coe.int/t/congress/sessions/18/Source/CharteEuropeenne_en.pdf (in English).

10. Official website of the Ministry of Regional Development, Building, Housing and Communal Services of Ukraine. Fiscal decentralization in action. Available at: http://www.minregion.gov.ua/decentralization/ presentation/finansova-detsentralizatsiya-v-diyi/ (in Ukrainian). 